\title{
STUDI ANALISIS PROKRASTINASI AKADEMIK MAHASISWA DALAM MENGERJAKAN SKRIPSI
}

\author{
Siti 'Aisyah, Eka Pramono Adi, Agus Wedi \\ Jurusan Teknologi Pendidikan, Fakultas Ilmu Pendidikan, Universitas Negeri Malang \\ Jalan Semarang 5 Malang 65145-574700 \\ Sitiaisyah4154sh@gmail.com
}

Article History

Received: 21 Januari 2021, Accepted: 19 Maret 2021, Published: 20 November 2021

\begin{abstract}
Abstrak
Penelitian ini bertujuan untuk mengetahui gambaran prokrastinasi akademik atau penundaan akademik mahasiswa dalam mengerjakan skripsi. Penelitian ini termasuk kedalam penelitian deskriptif pendekatan kuantitatif. Subjek penelitian adalah mahasiswa teknologi pendidikan. sedangkan teknik pengambilan sampel pada penelitian ini menggunakan metode convenience sampling. Data dalam penelitian dikumpulkan dengan menggunakan skala psikologi yaitu skala prokrastinasi akademik. Dari hasil pengumpulan data menunjukkan bahwa skor empirik yang lebih kecil dari skor mean teoritik. Hal itu menunjukkan bahwa subjek penelitian data lebih tinggi dari nilai rata-rata teoritik yang berarti subjek penelitian memiliki perilaku prokrastinasi akademik yang tergolong tinggi. Dengan hasil tersebut peneliti menyimpulkan adanya perbedaan rata-rata yang signifikan pada perilaku prokrastinasi akademik mahasiswa dan dapat dinyatakan bahwa perilaku prokrastinasi akademik mahasiswa TEP2016 dalam mengerjakan skripsi tinggi dan terbukti secara signifikan. Berdasarkan hasil dari penelitian ini diharapkan prodi dapat meningkatkan mutu pelayanan bimbingan skripsi agar dapat mengurangi peningkatan prokrastinasi akademik mahasiswa.
\end{abstract}

Keyword: Prokrastinasi; Akademik; Mahasiswa

\begin{abstract}
This study aims to determine the description of academic procrastination or academic delay of students in working on their thesis. This research is included in quantitative descriptive research. The research subjects were students of educational technology. while the sampling technique in this study using convenience sampling method. The data in the study were collected using a psychological scale, namely the academic procrastination scale. From the results of the survey the data shows that the empirical score is smaller than the theoretical mean score. This shows that the data research subject is higher than the theoretical average value, which means that the research subject has high academic procrastination behavior. With these results, the researchers concluded that there was a significant average difference in students' academic procrastination behavior and it could be stated that the academic procrastination behavior of educational technology students in 2016 in working on their high thesis proved to be significant. Based on the results of this study, it is expected that the study program can improve the quality of thesis guidance services in order to reduce the increase in student academic procrastination.
\end{abstract}

Keyword: Procrastination; Academic; Student 


\section{PENDAHULUAN}

Prokrastinasi akademik merupakan sebuah perilaku menunda-nunda mengerjakan tugas dibidang akademik. Kebiasaan ini sering dilakukan semua orang tanpa terkecuali mahasiswa. Dalam masa-masa kuliah mahasiswa sering dihadapkan dengan berbagai masalah seperti tuntutan dan berbagai pengambilan keputusan. Mahasiswa dituntut untuk menyelesaikan studinya dengan jangka waktu yang telah ditentukan oleh pihak kampus. Ketatnya persaingan mencapai prestasi membuat tekanan tersendiri untuk mahasiswa. Disisi lain mahasiswa ingin lulus dengan tepat waktu dan memiliki prestasi yang baik dimasa kuliah. Namun, disisi lain masih dihadapkan dengan permasalahan interpesonal baik dengan keluarga atau pertemanan.

Ferrari dan Scher (2000), mengatakan bahwa tolak ukur seseorang melakukan prokrastinasi akademik merupakan penundaan mengawali maupun menyelesaikan tugas yang dihadapi, lambatnya dalam mengerjakan tugas, Kesenjangan waktu antara rencana dengan mengerjakan dan menyelesaikan tugas, dan melakukan aktivitas lain yang lebih gemari dari pada mengerjakan tugas.

SAL salah satu mahasiswa semester akhir TEP2016 berpendapat bahwa tugas skripsi merupakan tugas akhir yang tidak mudah. Karena fenomena umumnya, mahasiswa mampu menyelesaikan matakuliah dengan tepat waktu, namun menjadi banyak rintangan ketika menyusun skripsi. Pada awalnya mahasiswa mempunyai semangat, motivasi serta minat yang tinggi untuk mengerjakan dan menyelesaikan skripsi namun pada prosesnya banyak mahasiswa yang kesulitan dalam menyelesaikan atau mengerjakan skripsi.

Ursia (2013), meneliti mengenai prokrastinasi dan self-control terhadap mahasiswa skripsi di fakultas psikologi Universitas Surabaya yang melibatkan 157 mahasiswa yang telah mengerjakan skripsi. Penelitian ini menguji Teori Motivasi Temporal atau TMT dalam pemaparannya pola hubungan antara self-control dan prokrastinasi akademik. Hasil penelitiannya menunjukan bahwa peran elemen-elemen TMT sebagai mediator menjadi terbukti ketika hubungan tidak baik tersebut dapat melemah secara akurat setelah dilaksanakan pengendalian pada ketiga elemen TMT. Meskipun demikian, pelemahan yang lebih besar justru ditemukan ketika self-control yang dijadikan sebagai variabel mediator.

Prokrastinasi akademik juga terjadi pada mahasiswa univeristas di Turki. Hasil penelitian milik Ozer \& Sackes (2011) menunjukkan bahwa sebanyak 118 dari 314 mahasiswa termasuk dalam prokrastinasi akademik golongan tinggi. Mahasiswa memiliki pandangan bahwa "tugas dikerjakan nanti" atau "lebih baik dikerjakan esok hari". Mereka yang tidak bisa memanfaatkan waktu dengan baik dan menunda pekerjaan ataupun suatu tugas adalah bagian indikasi dari prokrastinasi (Wolters et al., 2017).

Perbedaan penelitian yang peneliti lakukan dengan tiga penelitian sebelumnya adalah berdasarkan metode peneliti dilaksanakan teknik convenience sampling, menggunakan empat perspektif prokrastinasi dan menentukan Perspektif mana yang paling berpengaruh pada mahasiswa, melakukan observasi penelitian dan menggunakan angket prokrastinasi akademik mahasiswa. Tujuan penelitian ini untuk mendeskripsikan secara analisis prokrastinasi akademik mahasiswa S1 Prodi TEP angkatan 2016 dalam mengerjakan skripsi.

Berdasarkan hasil observasi yang dilakukan oleh peneliti sekitar 67\% mahasiswa TEP angkatan 2016 menyatakan kesulitan dalam menyusun atau menyelesaikan skripsi akibat dari banyaknya aktivitas lain dan 92,6\% menyatakan bahwa menyusun skripsi sangat membutuhkan tenaga yang ekstra. Hal ini bisa saja mahasiswa terjebak dalam prokrastinasi secara tidak sadar atau mahasiswa sudah termasuk melakukan prokrastinasi secara konsisten dan problematik.

Data yang tercatat pada bulan Januari 2020 oleh Subag Akademik Fakultas ilmu pendidikan Universitas Negeri Malang pada prodi S1 TEP tercatat bahwa mahasiswa angkatan 2016 yang sedang 
menempuh mata kuliah skripsi berjumlah 95 mahasiswa. Sedangkan untuk mahasiswa angkatan 2013 - 2015 masih ada 27 mahasiswa yang belum menyelesaikan masa studinya. Dari data ini menunjukkan bahwa masih beberapa mahasiswa TEPyang mengalami masalah dalam proses menyelesaikan studi lebih dari 4 tahun.

Dari sinilah Peneliti mengetahui bahwa fenomena prokrastinasi selalu terjadi di setiap angkatan. Jika hal ini terus berlanjut maka dapat meningkatkan rasio Drop Out (DO) pada mahasiswa, dan menurunkan kredibilitas dan kualitas prodi. Maka berdasarkan fenomena tersebut peneliti terdorong untuk melaksanakan pengkajian lebih dalam mengenai prokrastinasi akademik dengan judul "Studi Analisis Prokrastinasi Akademik dalam Mengerjakan Skripsi”.

\section{METODE}

Penelitian ini menggunakan pendekatan kuantitatif deskriptif. Menurut Susilo (2013), penelitian deskriptif merupakan penelitian yang dimanfaatkan untuk memahami variabel, satu variabel atau lebih, atau dengan menghubungkan variabel yang lain. Berdasarkan pemaparan di atas, maka variabel dalam penelitian ini adalah Variabel Tunggal, dimana peneliti hanya menggunakan satu variabel yaitu prokrastinasi mahasiswa Prodi S1 Teknologi Pendidikan.

Dalam penelitian ini sampel diambil dari keseluruhan jumlah populasi, sehingga penelitian ini merupakan penelitian populasi. Pengambilan populasi sebagai subjek penelitian ini juga berdasar pada pendapat Arikunto (1997) memaparkan apabila subjek kurang dari 100, lebih baik diambil semua sehingga penelitian ini termasuk penelitian populasi. Berdasarkan hal tersebut, jumlah subjek penelitian ini berjumlah 95 orang (populasi kecil) terdiri dari 3 Offering yaitu A, B dan C jurusan TEP angkatan 2016 Universitas Negeri Malang yang sedang mengerjakan skripsi.

Sedangkan untuk teknik pengambilan sampel penelitian ini adalah non Probabilitas yaitu Convenience sampling. Menurut Susilo (2013), Convenience sampling merupakan metode penentuan sampel dengan memilih sampel secara bebas sesuai kehendak peneliti. Metode pengambilan sempel ini dipilih untuk memudahkan pelaksanaan riset dengan alasan responden yang digunakan yaitu mahasiswa angkatan 2016 dan masih mengerjakan dan menyusun skripsi.

Teknik pengumpulan data pada penelitian ini adalah Observasi dan Kuesioner atau angket.Adapun angket yang digunakan yaitu angket tertutup. Angket tertutup merupakan angket yang gunakan dalam bentuk semacam itu sehingga subjek penelitian diminta untuk memutuskan satu jawaban yang sesuai dengan ciri khas dirinya. Dalam penelitian menggunakan skala Likert. Bentuk dari angket skala Likert yang digunakan yaitu angket tertutup dengan butir-butir pernyataan serta pilihan jawaban yang paparkan kepada subjek adalah opsi jawaban yang sesuai dengan keadaan dirinya, diantaranya sangat sesuai (SS) skoring 4, sesuai (S) soring 3, tidak sesuai (TS) skoring 2, dan sangat tidak sesuai (STS) skoring 1.

Instrumen penelitian prokrastinasi akademik disusun berdasarkan empat perspektif prokrastinasi yang dikemukakan oleh ferarri antara lain penundaan mengawali maupun menyelesaikan tugas yang dihadapi, lambatnya dalam mengerjakan tugas, Kesenjangan waktu antara rencana dengan mengerjakan dan menyelesaikan tugas, dan melakukan aktivitas lain yang lebih gemari dari pada mengerjakan tugas. Untuk mengetahui instrumen layak digunakan diperlukan alat ukur penelitian yaitu pengujian validitas.

Penghitungan validitas pada penelitian ini memakai rumus korelasi product moment atau yang dikenal dengan korelasi pearson. Kriteria butir pernyataan yang valid dengan melihat tabel nilai-nilai korelasi Product Moment. Kemudian menggunakan Uji reliabilitas instrumen yaitu tahapan mengetahui tingkat konsisten angket (kuesioner) yang digunakan untuk penelitian. Uji reliabilitas instrumen dengan menggunakan rumus Formula Alpha Cronbach dan dengan bantuan program spss 16.0 for windows. Sedangkan prediksi reliabilitas dilakukan dengan menggunakan kriteria reliabilitas. 
Dilanjutkan teknik analisis penelitian yang mencakup perhitungan-perhitungan sederhana yang biasanya disebut sebagai statistik dasar, yang antara lain perhitungan frekuensi, frekuensi kumulatif, persentase, skor maksimum dan skor minimum, dan rata-rata hitung Nurgiyantoro \& Efendi (2013), Setelah data penelitian sudah terkumpul kemudian dilakukan penggolongansasian variabel penelitian.

Penentuan golongan kecenderungan tiap-tiap variabel berdasarkan norma atau ketentuan golongan pada masing-masing variabel dengan menggunakan ketentuan Norma golongansasi disusun berdasarkan mengelompokkan tingkat prokrastinasi akademik pada mahasiswa TEPangkatan 2016 ke dalam lima golongansasi antara lain sangat rendah, rendah, sedang, tinggi, dan sangat tinggi. Dari Norma golongansasi prokrastinasi akademik inilah peneliti dapat mengetahui gambaran prokrastinasi akademik mahasiswa. Dan untuk membuktikan bahwa mahasiswa TEP benar adanya memiliki gambaran prokrastinasi akademik menggunakan dengan uji normalitas data dan uji statistik One Sample T-test dengan membandingkan mean teorotik dan mean empirik.

Pengujian ini menggunakan dengan dasar uji hipotesis. Hasil keputusan didasarkan pada angka signifikasi (p): Jika (p) > 0,05 maka Ho diterima dan Ha ditolak. Sedangkan jika (p) < 0,05 maka Ho ditolak dan Ha diterima. Ho adalah rumus hipotesis awal yaitu tidak ada perbedaan yang signifikasi antara mean teoritik dengan mean empirik. Ha atau hipotesis alternatif merupakan adanya perbedaan yang signifikan antara mean teoritik dengan mean empirik Peneliti juga melakukan perbandingan analisis terhadap empat Perspektif prokrastinasi serta peneliti juga melakukan analisis tambahan terhadap antara lain (prokrastinasi akademik berdasarkan Jangka waktu pengerjaan skripsi, jenis kelamin dan kegiatan lain mahasiswa yang menimbulkan prokrastinasi akademik) Jadi, terdapat lima analisis yang bisa mencangkup gambaran prokrastinasi dengan pembuktian yang relevan,

\section{HASIL}

Gambaran tingkat prokrastinasi atau penundaan akademik mahasiswa menunjukkan hasil bahwa tingkat prokrastinasi atau penundaan akademik mahasiswa TEP angkatan 2016 sangat tinggi. Dari akumulasi tanggapan responden dapat diketahui bahwa variabel prokrastinasi akademik mahasiswa TEP 2016 memiliki nilai jawaban rata-rata yang tertinggi yaitu 3,43 dan nilai jawaban yang terendah yaitu 2,68 sedangkan total rata-rata jawaban responden untuk 33 item pernyataan adalah 100,82. Jadi, dapat disimpulkan bahwa secara umum prokrastinasi akademik mahasiswa TEP 2016 UM memiliki kreteria tinggi.

Hal ini dibuktikan dengan teknik analisis uji normalitas, diketahui mean empirik diperoleh 100.82 sedangkan mean teoritik sebesar 82,5. Terlihat dari hasil tersebut nilai mean empirik lebih besar dari nilai mean teoritik. Jadi, kecenderungan responden penelitian data lebih tinggi dari nilai rata-rata teoritik yang berarti responden memiliki sikap prokrastinasi atau penundaan akademik yang tergolong tinggi. Kemudian hasil perbandingan mean empirik dengan mean teoritik diuji lagi dengan uji statistik One Sample T-test untuk membuktikan bahwa mean empirik secara relevan lebih besar dari mean teoritik.

Berdasarkan perhitungan uji statistik One Sample T-test diketahui bahwa t-hitung sebesar 12.473 dan dari data t- tabel taraf kepercayaan 95\% dengan derajat kebebasan sebesar 64 di dapat nilai t-tabel sebesar 1,998. Sedangkan nilai signifikasinya (p) adalah 0,000 lebih kecil dari 0,05 ( p) $=0.000<0.05$ Hal ini menunjukkan ada perbedaan rata-rata yang relevan mean empirik dengan mean teoritik. Secara signifikan mean empirik lebih besar dari mean teoritik. Dengan hasil tersebut diketahui adanya perbedaan rata-rata yang signifikan pada perilaku prokrastinasi akademik mahasiswa. Jadi, dapat disimpulkan mahasiswa TEP2016 memiliki prokrastinasi yang tinggi dan terbukti secara signifikan. oleh karena itu t-hitung $>$ t-tabel $(12.473>1.998)$ dan nilai $\mathrm{p}<0,05$. kemudian pada masing-masing Perspektif prokrastinasi akademik pada mahasiswa TEP 2016 dapat dilihat pada tabel 1. Deskriptif setiap perspektif. 
Tabel 1. Hasil Deskriptif Setiap Perspektif Prokrastinasi Akademik

\begin{tabular}{|c|c|c|c|c|c|}
\hline \multirow{2}{*}{ No. } & \multirow{2}{*}{ Keterangan } & \multicolumn{4}{|c|}{ Perspektif prokrastinasi akademik } \\
\hline & & $\mathbf{A}$ & B & C & D \\
\hline 1 & $\mathrm{~N}$ & 65 & 65 & 65 & 65 \\
\hline 2 & Skor Min Teoritik & 8 & 7 & 9 & 9 \\
\hline 3 & Skor Min Empirik & 16 & 14 & 18 & 18 \\
\hline 4 & Skor Maks Teoritik & 32 & 28 & 36 & 36 \\
\hline 5 & Skor Maks Empirik & 32 & 26 & 34 & 34 \\
\hline 6 & Mean Teoritik & 20 & 17,5 & 22,5 & 22,5 \\
\hline 7 & Mean Empirk & 25.49 & 20.71 & 27.45 & 27.17 \\
\hline 8 & Median & 26.00 & 20.00 & 27.00 & 27.00 \\
\hline 9 & Modus & 23 & 19 & 25 & 30 \\
\hline 10 & Standar Deviasi Teoritik & 4 & 3,5 & 4,5 & 4,5 \\
\hline 11 & Standar Deviasi Empirik & 3.248 & 2.919 & 3.248 & 3.591 \\
\hline 12 & Standar Eror & 0.425 & 0.362 & 0.425 & 0.445 \\
\hline
\end{tabular}

Penjelasan pada tabel 1. Deskripsi setiap perspektif prokrastinasi akademik. Pada perspektif A merupakan penundaan untuk mengawali maupun menyelesaikan tugas yang dihadapi. Perspektif B merupakan keterlambatan dalam mengerjakan skripsi. Perspektif $\mathrm{C}$ merupakan kesenjangan waktu antara rencana dan penyelesaian tugas. Dan perspektif D merupakan melakukan kegiatan lain yang menyenangkan dari pada mengerjakan tugas.

Keempat Perspektif prokrastinasi memiliki nilai mean empirik lebih tinggi daripada mean teoritik hal ini juga bandingkan dengan Hasil Uji Statistik One Sample T-Test perspektif prokrastinasi pada tabel 2. Hasil uji statistik.

\section{Tabel 2. Hasil Uji Statistik One Sample T-Test Perspektif Prokrastinasi}

\begin{tabular}{llll}
\hline Perspektif & Nilai t & $\mathbf{P}<\mathbf{0 , 0 5}$ & Keterangan \\
\hline A & 12.916 & 0.000 & Signifikan \\
B & 8.859 & 0.000 & Signifikan \\
C & 11.633 & 0.000 & Signifikan \\
D & 10.484 & 0.000 & Signifikan \\
\hline
\end{tabular}

Berdasarkan hasil Keempat Perspektif diatas terbukti secara signifikan atau relevan. Hal ini mengindikasikan bahwa perilaku responden penelitian yang termanifestasikan dalam Perspektif prokrastinasi akademik adalah tinggi.

Sedangkan berdasarkan analisis prokrastinasi atau penundaan akademik berdasarkan jenis kelamin. Perhitungan uji statistik Independent Sample T-test diketahui bahwa F-hitung 0,849 dengan $\mathrm{p}$ (sig) 0,360 oleh karena $\mathrm{p}>0,05$ maka dua kelompok populasi memiliki kesamaan varian (homogenitas) dengan kata lain kedua varian memiliki populasi yang sama. Nilai t-hitung sebesar 0,447 dan dari t-tabel pada taraf kepercayaan 95\% dengan derajat kebebasan sebesar 63 di dapat nilai t-tabel sebesar 1,998 sedangkan nilai $\mathrm{p}$ (sig. 2- tailed) sebesar 0,656 ( $\mathrm{p}=0,656>0,05)$ oleh karena thitung < t-tabel $(0,447<1,998)$ dan nilai $\mathrm{p}>0,05$ maka diambil keputusan bahwa Ho diterima dan Ha ditolak. Uji hipotesis memaparkan hasil keputusan didasarkan pada angka Jika (p) > 0,05 Maka Ho diterima dan Ha ditolak Jika (p) < 0,05 Maka Ho ditolak dan Ha diterima. Ho atau hipotesis awal yaitu ada tidaknya perbedaan perilaku prokrastinasi atau penundaan akademik antara wanita dan pria. Ha atau hipotesis alternatif adanya perbedaan sikap prokrastinasi atau penundaan akademik antara wanita dan pria. Dapat dilihat pada tabel 3. Deskriptif data penelitian 
Tabel 3. Deskripsi Data Penelitian Berdasarkan Jenis Kelamin Independent Sample T-Test

\begin{tabular}{ccccccccc}
\hline & Gender & N & Mean & $\begin{array}{c}\text { Std. } \\
\text { Deviation }\end{array}$ & f & p & t & sig (2-tailed) \\
\hline $\begin{array}{c}\text { Total } \\
\text { Prokrastinasi }\end{array}$ & Laki laki & 29 & 101.55 .00 & 12.833 & 0.849 & 0.360 & 0.447 & 0.656 \\
& Wanita & 36 & 100.22 .00 & 11.123 & & & &
\end{tabular}

Rata-rata skor yang menyatakan bahwa mahasiswa pria lebih tinggi yaitu 101.55 .00 daripada mahasiswa wanita dengan nilai rata-rata 100.22.00. Setelah diuji kan dapat disimpulkan bahwa tidak ada perbedaan perilaku prokrastinasi akademik yang signifikan pada jenis kelamin antara pria dan wanita dengan perilaku yang sama.

Pada analisis tambahan Jangka waktu pengerjaan skripsi yang dilakukan mahasiswa pengerjaan secara keseluruhan dapat dilihat bahwa $18 \%$ atau 12 pria dan $2 \%$ atau 1 wanita memilih mengerjakan skripsi kurang dari 3 jam perhari. Diikuti dengan 20\% atau 13 pria dan $37 \%$ atau 24 wanita memilih mengerjakan skripsi lebih dari 3 jam perhari. Dan 6\% atau 4 pria dan $17 \%$ atau 11 wanita memilih mengerjakan skripsi sepanjang hari. Dapat disimpulkan bahwa mengerjakan skripsi lebih dari 3 jam perhari memiliki presentase yang tinggi.

Terakhir, analisis tambahan secara keseluruhan dapat dilihat bahwa $29 \%$ atau 19 pria dan $2 \%$ atau 1 wanita memilih bermain game. $0 \%$ atau 0 pria tidak memilih dan $34 \%$ atau 22 wanita memilih aktivitas menonton film. Diikuti $9 \%$ atau 6 pria dan $14 \%$ atau 9 wanita memilih aktivitas jalan-jalan. Dan 6\% atau 4 pria dan 6\% atau 4 wanita memilih aktivitas bekerja. Dapat disimpulkan jika menonton film merupakan aktivitas yang tinggi dilakukan mahasiswa TEP dalam prokrastinasi atua penundaan akademik.

\section{PEMBAHASAN}

Gambaran prokrastinasi atau penundaan akademik Mahasiswa TEP 2016 UM informasi yang dikumpulkan melalui kuesioner yang diberikan kepada mahasiswa TEP 2016 diketahui sebagian besar mahasiswa yakni $38 \%$ atau 25 mahasiswa dengan golongan prokrastinasi sangat tinggi, $40 \%$ atau 26 mahasiswa dengan golongan prokrastinasi tinggi, 20\% atau 13 mahasiswa dengan prokrastinasi golongan sedang, dan $2 \%$ atau 1 mahasiswa dengan prokrastinasi golongan rendah.

Berdasarkan nilai skor mean empiris 100,82 lebih besar daripada skor mean teoritis dengan nilai 82,5. Dan nilai signifikasinya 0,000 lebih kecil dari 0,05. Hasil tersebut menunjukkan bahwa sebagian sebesar mahasiswa TEP angkatan 2016 UM memiliki perilaku prokrastinasi akademik dalam mengerjakan dan menyelesaikan skripsi tergolong tinggi dan terbukti secara relevan.

Hasil penelitian prokrastinasi atau penundaan akademik yang dilakukan mahasiswa TEP angkatan 2016 didukung dengan perhitungan analisis deskriptif mengenai perbandingan kedudukan perspektif prokrastinasi karena menurut Ferrari (1995) Terdapat empat Perspektif prokratinasi akademik yang digunakan sebagai tolak ukur seseorang dapat dikatakan sebagai prokrastinator dan peneliti memaparkan hasil setiap Perspektif sebagai berikut: Secara keseluruhan terdapat 52\% atau 35 mahasiswa pada Perpektif penundaan golongan sangat tinggi, 37\% atau 24 mahasiswa pada Perspektif penundaan golongan tinggi, 9\% atau 6 mahasiswa pada perspektif penundaan golongan sedang, dan $2 \%$ atau 1 mahasiswa pada perspektif penundaan golongan rendah.

Berdasarkan hasil skor mean empiris 25,49 lebih besar daripada skor mean teoritis bernilai 20 . Dan nilai signifikasinya 0,000 lebih kecil dari 0,05. Dari perolehanya menunjukkan bahwa sebagian sebesar mahasiswa TEP angkatan 2016 UM melakukan prokrastinasi untuk mengawali maupun menyelesaikan skripsi yang dihadapi tergolong sangat tinggi dan terbukti secara relean.

Pada perspektif keterlambatan dalam mengerjakan skripsi secara keseluruhan terdapat 32\% atau 21 mahasiswa mendapat hasil dari pengujian perspektif keterlambatan dengan golongan sangat 
tinggi, 31\% atau 20 mahasiswa pada perspektif keterlambatan golongan tinggi, $32 \%$ atau 21 mahasiswa pada perspektif keterlambatan golongan sedang, dan 5\% atau 3 mahasiswa pada perspektif keterlambatan golongan rendah.

Berdasarkan hasil skor mean empiris 20,71 lebih besar daripada skor mean teoritis dengan nilai 17,5. Dan nilai signifikasinya 0,000 lebih kecil dari 0,05. Hasil tersebut memperlihatkan bahwa sebagian sebesar mahasiswa TEP angkatan 2016 UM melakukan keterlambatan dalam mengerjakan tugas skripsi tergolong sangat tinggi dan terbukti signifikan.

Hasil penelitian juga sejalan dengan penelitian (Saman, 2017) menggolongankan Kelambanan dalam mengerjakan tugas menunjukkan hasil dengan presentasi prokrastinasi atau penundaan akademik dalam golongan sedang 41,3\% dan golongan tinggi dengan presentasi 33.91. Melihat sajian data presentasi dapat mengindikasikan bahwa perilaku prokrastinasi cenderung disebabkan oleh kelambanan dalam mengerjakan tugas.

Menurut Ferrari (1995), kelambanan sesorang dalam melakukan suatu tugas dapat menjadi ciri utama dalam prokrastinasi atau penundaan akademik. Sedangkan Knaus (2000), menyatakan ada beberapa alasan yang menyebabkan pelajar atau mahasiswa melakukan prokrastinasi diantaranya pengelolaan waktu yang buruk, sulit berkonsentrasi, irasional dan bosan dalam mengerjakan tugas. Alasan tersebut yang membuat seseorang lambat dalam menyelesaikan tugasnya membentuk seseorang yang lamban dalam mengerjakan dan menyelesaikan tugas skripsi.

Pada perspektif kesenjangan waktu antara rencana dan penyelesaian tugas. Secara keseluruhan terdapat 35\% atau 23 mahasiswa pada Perspektif kesenjangan waktu golongan sangat tinggi, $45 \%$ atau 29 mahasiswa pada Perspektif kesenjangan waktu golongan tinggi, 18\% atau 12 mahasiswa pada Perspektif kesenjangan waktu golongan sedang, dan $2 \%$ atau 1 mahasiswa pada Perspektif Kesenjangan waktu golongan rendah.

Berdasarkan hasil skor mean empiris 27,45 lebih besar daripada skor mean teoritis dengan nilai 22,5. Dan nilai signifikasinya 0,000 lebih kecil dari 0,05. Hasil tersebut menunjukkan bahwa sebagian sebesar mahasiswa TEP angkatan 2016 UM melakukan kesenjangan waktu antara rencana dan penyelesaian tugas skripsi tergolong tinggi dan terbukti signifikan.

Menurut Ferrari (1995), Seorang prokrastinator akan selalu mengalami keterlambatan dalam pengerjaan tugas yang dihadapinya, baik itu tugas dari orang lain maupun rencana yang di buat untuk dirinya sendiri. Sedangkan menurut Catrunada (2008), mengatur waktu berarti mampu memperkirakan dengan baik berapa lama yanng dibutuhkan untuk menyelesaikan tugas. Lemahnnya dalam mengatur waktu membuat seseorang sulit memutuskan pekerjaan yang penting dan kurang penting untuk dikerjakan hari ini. Dari pendapat maka dilakukan menganalisis berapa jangka waktu yang dibutuhkan mahasiswa TEP angkatan 2016 dalam mengerjakan skripsi perhari.

Peneliti membagi jangka waktu atau lamanya pengerjaan menjadi 3 golongan yang pertama Terdapat 13 mahasiswa yang memilih jangka waktu kurang dari 3 jam perhari dalam mengerjakan tugas, 37 mahasiswa yang memilih jangka waktu lebih dari 3 jam perhari dalam mengerjakan tugas dan 15 mahasiswa memilih jangka waktu sepanjang hari untuk mengerjakan tugas. Dengan mengetahui berapa lama jangka waktu yang dibutuhkan mahasiswa setiap harinya akan membantu mempermudah mahasiswa menyelesaikan tugas dengan teratur dan terarah jika dilakukan dengan disiplin waktu yang benar.

Kesenjangan waktu antara rencana dan penyelesaian tugas juga bisa terbentuk karena adanya kebiasaan mahasiswa yang mengganggap remeh. Tugas skripsi yang dianggap mudah dan dengan dead line pengumpulan yang panjang inilah yang membuat mahasiswa meremehkan pengerjaan dan penyelesaianya. 
Pada Perspektif terakhir Melakukan Aktivitas Lain yang Lebih Menyenangkan dari Pada Mengerjakan Tugas Secara keseluruhan terdapat 40\% atau 26 mahasiswa pada Perspektif aktivitas lain dengan golongan sangat tinggi, $32 \%$ atau 21 mahasiswa pada aktivitas lain golongan tinggi, $25 \%$ atau 15 mahasiswa pada Perspektif aktivitas lain dengan golongan sedang, dan 3\% atau 2 mahasiswa mendapat pada Perspektif aktivitas lain golongan rendah.

Berdasarkan hasil skor mean empiris 27,17 lebih besar daripada skor mean teoritis dengan nilai 22,5. Dan nilai signifikasinya 0,000 lebih kecil dari 0,05. Hasil tersebut menunjukkan bahwa sebagian sebesar mahasiswa TEP angkatan 2016 universitas negeri malang Melakukan aktivitas lain yang lebih menyenangkan dari pada mengerjakan tugas skripsi tergolong sangat tinggi dan terbukti signifikan.

Sebagai bukti pendukung peneliti juga menganalisis kegiatan atau Aktivitas lain yang membuat mahasiswa melakukan prokrastinasi akademik. Aktivitas lain inilah digolongkan menjadi empat golongan. Golongan pertama untuk bermain game terdapat 20 mahasiswa yang memilih, golongan kedua untuk menonton film terdapat 22 mahasiswa yang memilih, golongan ketiga jalan-jalan atau rekreasi terdapat 15 mahasiswa yang memilih, golongan terakhir adalah bekerja terdapat 8 mahasiswa yang memilih. Hal ini juga didukung dengan penelitian Mayasari et (2012), sekitar 55\% mahasiswa menunda untuk memulai atau mengerjakan skripsi dan memilih untuk melakukan aktivitas lain yang lebih menyenangkan. Disamping itu mahasiswa merasa dirinya sudah cukup dewasa untuk mengatur jadwal kegiatan mereka sendiri. Terlebih mahasiswa menganggap dirinya adalah individu yang bebas dan tidak mau diatur oleh aturan-aturan lain yang mengganggu kesenangan mereka. Sedangkan menurut sebenarnya pemanfaatan waktu luang yang baik cenderung akan mengurangi resiko terjadinya prokrastinasi akademik.

Peneliti juga menemukan faktor lain terkait penyebab prokratinasi akademik, yaitu berdasarkan penelitian dari Uztemur (2020), yang meneliti mahasiswa di Public University of South Turkey yang sebanyak 184 mahasiswa menggunakan dua jenis pengambilan data yaitu Social Media Addiction Scale for Adolescents untuk mengukur skala adiksi sosial media para mahasiswa dan Tuckman Procrastination Scale untuk mengukur skala prokrastinas akademik. Hasil penelitian Uztemur (2020), menunjukkan bahwa kecanduan sosial media berhubungan dengan prokrastinasi akademik tetapi tidak berhubungan dengan kesuksesan akademik.

Sedangkan penelitian Meeter (2020), yang meneliti tentang penurunan motivasi belajar di masa pandemi covid-19. Terdapat sejumlah 166 responden mahasiswa fakultas psikologi di Dutch research university. Hasilnya dari penelitian menunjukkan bahwa motivasi belajar menurun di masa pandemi covid-19, karena anjuran dirumah membuat motivasi mahasiswa menurun sehinga menyebabkan adanya prokrastinasi akademik.

\section{SIMPULAN}

Berdasarkan hasil penelitian dan pembahasan pada bab sebelumnya dapat disimpulkan bahwa 65 dari 95 mahasiswa TEP angkatan 2016 jika dipersentasekan 68,42\% dari jumlah keseluruhan mahasiswa menyatakan bahwa mahasiswa berada dalam golongan tinggi dalam perilaku prokrastinasi akademik, dan juga membuktikan ada tidaknya perbedaan tindakan prokrastinasi akademik berdasarkan jenis kelamin. Hasil penelitian gambaran prokrastinasi akademik mahasiswa TEP didukung dengan perhitungan analisis deskriptif mengenai perbandingan empat perspektif prokrastinasi akademik yang menjadi tolak ukur adanya perilaku prorastinasi atua penundaan akademik yang seluruhnya dinyatakan tinggi dan signifikan. Penelitian ini akan terasa sempurna jika peneliti selanjutnya mampu meneliti perbandingan antar angkatan mahasiswa TEP yang belum mengakhiri masa studi lebih dari 5 tahun dan dapat mengetahui faktor prokrastinasi atau penundaan akademik yang terjadi pada mahasiswa antar angkatan tersebut. 


\section{DAFTAR RUJUKAN}

Arikunto, S. (1997). Penilaian Program Pendidikan Edisi Ketiga. Jakarta: Bina Aksara.

Catrunada, L. (2008). Perbedaan Kecenderungan Prokastinasi Tugas Skripsi Berdasarkan Tipe Kepribadian Introvert dan Eksrovert. Skripsi (tidak diterbitkan). Fakultas Psikologi Universitas Gunadarma.

Clariana, M. (2013). Personality, procrastination and cheating in students from different university degree programs. Electronic Journal of Research in Educational Psychology.

Ferrari, J. R., \& Roster, C. A. (2018). Delaying disposing: examining the relationship between procrastination and clutter across generations. Current Psychology, 37(2), 426-431.

Ferrari, J. R., \& Scher, S. J. (2000). Toward an understanding of academic and nonacademic tasks procrastinated by students: The use of daily logs. Psychology in the Schools, 37(4), 359-366.

Goroshit, M., Hen, M., \& Ferrari, J. R. (2020). Life-domain regret regarding procrastination (LDR-P): Scale validation in the United States and Israel. Current Psychology, 39(3), 900-912.

Husetia, Y. (2010). Hubungan asertivitas dengan prokrastinasi akademik pada mahasiswa Fakultas Psikologi Universitas Diponegoro Semarang. UNDIP.

Knaus, W. J. (2000). Procrastination, blame, and change. Journal of Social Behavior and Personality, 15(5), 153.

Kuss, D. J., \& Griffiths, M. D. (2011). Online social networking and addiction-a review of the psychological literature. International journal of environmental research and public health, 8(9), 3528-3552.

Lowinger, R. J., Kuo, B. C., Song, H. A., Mahadevan, L., Kim, E., Liao, K. Y. H., ... \& Han, S. (2016). Predictors of academic procrastination in Asian international college students. Journal of Student Affairs Research and Practice, 53(1), 90-104.

Mayasari, M. D., Mustami'ah, D., \& Warni, W. E. (2012). Hubungan antara persepsi mahasiswa terhadap metode pengajaran dosen dengan kecenderungan prokrastinasi akademik pada mahasiswa Fakultas Psikologi Universitas Hang Tuah Surabaya. Jurnal Insan Media Psikologi, 12(2).

Meeter, M., Bele, T., den Hartogh, C., Bakker, T., de Vries, R. E., \& Plak, S. (2020). College students motivation and study results after COVID-19 stay-at-home orders.

Nurgiyantoro, B., \& Efendi, A. (2013). Prioritas penentuan nilai pendidikan karakter dalam pembelajaran sastra remaja. Jurnal Cakrawala Pendidikan, 3(3).

Ozer, B. U., \& Saçkes, M. (2011). Effects of academic procrastination on college students' life satisfaction. Procedia - Social and Behavioral Sciences, 12(December), 512-519. https://doi.org/10.1016/j.sbspro.2011.02.063

Rahardjo, W., Juneman, J., \& Setiani, Y. (2013). Computer anxiety, academic stress, and academic procrastination on college students. Journal of Education and Learning, 7(3), 147-152.

Rumiani, R. (2006). Prokrastinasi Akademik Ditinjau dari Motivasi Berprestasi dan Stres Mahasiswa. Jurnal Psikologi Undip, 3(2), 128210.

Saman, A. (2017). Analisis Prokrastinasi Akademik Mahasiswa (Studi Pada Mahasiswa Jurusan Psikologi Pendidikan Dan Bimbingan Fakultas Ilmu Pendidikan). Jurnal Psikologi Pendidikan Dan Konseling: Jurnal Kajian Psikologi Pendidikan Dan Bimbingan Konseling, 55-62.

Shen, R., \& Liu, M. (2019). Time-Orientation, Social Media Use, and Coping Style: Cultural Similarities and Differences in How and Why College Students Procrastinate. China Media Research, 15(3).

Solomon, L. J., \& Rothblum, E. D. (1984). Academic procrastination: Frequency and cognitivebehavioral correlates. Journal of Counseling Psychology, 31(4), 503. 
Steel, P., \& Ferrari, J. (2013). Sex, education and procrastination: An epidemiological study of procrastinators' characteristics from a global sample. European Journal of Personality, 27(1), 51-58.

Stockwell, D. R. B., \& Peterson, A. T. (2002). Effects of sample size on accuracy of species distribution models. Ecological Modelling, 148(1), 1-13.

Ursia, N. R., Siaputra, I. B., \& Sutanto, N. (2013). Prokrastinasi Akademik Dan Self-Control Pada Mahasiswa Skripsi Fakultas Psikologi Universitas Surabaya-Academic Procrastination And Self-Control In Thesis Writing Students Of Faculty Of Psychology, Universitas Surabaya. Makara Seri Sosial Humaniora, 17(1), 1-18.

Uztemur, S. (2020). The Mediating Role of Academic Procrastination Behaviours in the Relationship Between Pre-Service Social Studies Teachers' Social Media Addiction and Academic Success. International Journal of Education Technology and Scientific Researches, 5, 63-101. https://doi.org/10.35826/ijetsar.112

Wolters, C. A., Won, S., \& Hussain, M. (2017). Examining the relations of time management and procrastination within a model of self-regulated learning. Metacognition and Learning, 12(3), 381-399. 